\title{
PROSPEK PEMANFAATAN LIMBAH BATANG PISANG DALAM MENDUKUNG EKONOMI KREATIF MASYARAKAT RAMAH LINGKUNGAN
}

\author{
Hutwan Syarifuddin*1, Hamzah ${ }^{2}$ \\ ${ }^{1,2}$ Program Studi Ilmu Lingkungan Pascasarjana Universitas Jambi \\ Jl. H.A. Manaf Kampus Unja Telanaipura Jambi 36122 \\ E-mail: hutwan@yahoo.co.id
}

\begin{abstract}
Dedication has been carried out in the Farmers Group (Canggam Craftfirra) and Karya Maju Farmers Group on Pematang Rahim Village, Mendahara Ulu District, East Tanjung Jabung Regency. Implementation of service for 8 months from May to November 2018. Objectives for empowering group members in supporting the banana cultivation program and processing banana stem waste as an environmentally friendly paper raw material. The results of dedication activities show that high public interest in utilizing the technology of processing banana stem waste as a raw material for paper to make household handicrafts (home industry) is caused so far Banana stem waste is only wasted and has not been processed into paper pulp. The use of banana stem waste has the advantage of being easily available, easy to do and the price is relatively cheap, so that its use will provide benefits for farmer groups and craftsmen. The prospect of using banana stem waste can be applied to support the creative economy.
\end{abstract}

Keywords: Waste Banana Stems, Paper Pulp, Handicrafts

\begin{abstract}
Abstrak
Pengabdian telah dilaksanakan di Kelompok Tani (Canggam Craftfirra) dan Kelompok Tani Karya Maju Desa Pematang Rahim Kecamatan Mendahara Ulu Kabupaten Tanjung Jabung Timur. Pelaksanaan pengabdian selama 8 bulan dari bulan Mei sampai Nopember 2018. Tujuan untuk pemberdayaan anggota kelompok dalam mendukung program budidaya pisang dan pengolahan limbah batang pisang sebagai bahan baku kertas ramah lingkungan. Hasil dari kegiatan pengabdian menunjukkan bahwa animo masyarakat yang tinggi untuk memanfaatkan teknologi pengolahan limbah batang pisang sebagai bahan baku kertas untuk membuat kerajinan rumah tangga (home industri). Hal ini disebabkan selama ini limbah batang pisang hanya terbuang dan belum diolah menjadi bubur kertas. Pemanfaatan limbah batang pisang mempunyai keunggulan mudah didapat, mudah dilakukan dan harganya relatif murah, sehingga dengan penggunaannya akan memberikan keuntungan bagi kelompok tani dan pengrajin. Prospek pemanfaatan limbah batang pisang dapat diaplikan untuk mendukung ekonomi kreatif.
\end{abstract}

Kata kunci: Limbah Batang Pisang, Bubur Kertas, Kerajinan Tangan.

\section{PENDAHULUAN}

Desa Pematang Rahim dengan luas $91,90 \mathrm{~km}^{2}$ merupakan salah satu desa yang yang ada di Kecamatan Mandahara Ulu dengan luas $381.30 \mathrm{~km}^{2}$. Jumlah penduduk Desa Pematang Rahim 3.577 jiwa, mata pencaharian penduduk Pematang Rahim sebagai petani, nelayan, pedagang, perbengkelan, dan PNS. Penduduk sebagai petani sebanyak (407 kepala keluarga) yang menanam berbagai jenis tanaman dengan komoditas unggulan kelapa sawit, selain itu terdapat tanaman holtikultura seperti pisang dengan jumlah pohon sebanyak 42.100 pohon dengan produksi buah pisang 1.020 kuintal [3].

Batang pohon pisang dibagi menjadi dua, yaitu batang semu yang merupakan tumpukan pelepah daun, sedangkan batang asli yang biasa dikenal dengan bonggol pisang. Bonggol pisang merupakan salah satu bagian dari pohon pisang yang kurang dimanfaatkan dan dianggap sebagai limbah perkebunan dan sering kali dibuang begitu saja. Dalam budidaya pisang (banana) di Desa Pematang Rahim memiliki keunggulan seperti masih tersedia lahan yang cukup untuk penanaman 
pohon pisang, mudah dalam penanganan, sumberdaya bibit batang pisang berlimpah, partisipasi petani yang tinggi dalam menanam pohon pisang, sudah terbentuk kelompok tani, adanya kreatifitas anggota kelompok dalam mengolah limbah batang pisang, kerjasama yang harmonis antara masyarakat dengan petugas penyuluh lapangan, dan buah pisang yang dihasilkan disukai konsumen. Partisipasi masyarakat dalam perumusan program membuat masyarakat tidak sematamata berkedudukan sebagai konsumen tetapi sebagai pelaku kegiatan [7] dan [8].

Kemudian dalam budidaya pisang di Desa Pematang Rahim masih ditemukan kelemahan berupa keterbatasan modal yang dimiliki petani, masih kurang sarana dan prasarana dalam pengolahan industri kreatif batang pisang dari hulu ke hilir, keterampilan sumberdaya manusia (petani yang masih rendah) dalam menghasilkan industri kreatif, desain/model yang dihasilkan belum bervariasi dan masih terbatasnya promosi yang dilakukan oleh kelompok masyarakat yang mengolah batang pisang menjadi industri kreatif seperti handy craft, serta belum adanya bantuan kredit dari pihak bank untuk petani yang menanam pisang.

Faktor eksternal yang mempengaruhi keberhasilan dari industri ramah lingkungan dengan bahan baku dari limbah batang pisang adalah permintaan konsumen tinggi, pemasaran lancar, sarana lalu lintas jalan lancar dari pusat kota Provinsi Jambi menuju Desa Pematang Rahim, adanya dukungan dari pemerintah daerah dalam pengembangan industri kreatif. Selain itu masih ada tantangan yang dihadapi oleh petani dalam pengembangan industri kreatif seperti masih adanya hama (babi hutan dan monyet) yang merusak tanaman pisang, bencana banjir alam, persaingan dengan produk lain yang ada di Provinsi Jambi [9].

Prospek pengolahan limbah batang pisang sebagai bahan baku industri kreatif yang ramah lingkungan menjadi suatu upaya untuk dapat meningkatkan perekonomian petani. Kondisi existing dalam menghasilkan bahan industri kreatif seperti kertas selalu menggunakan bahan serat yang berasal dari kayu akasia, dan kayu jabon. Kendala yang dihadapi adalah membutuhkan waktu yang lama untuk mendapatkan kayu akasia dan jabon, harganya mahal, sedangkan limbah pohon pisang mudah didapat dan harga yang tidak mahal [10]. Pemanfaatan limbah batang pisang mempunyai keunggulan antara lain; mudah didapat, mudah dilakukan dan harganya relatif murah [9]. Batang pisang memiliki komposisi $76 \%$ pati, $20 \%$ air, sisanya adalah protein dan vitamin [1]. Menurut [10] kandungan batang pisang antara lain: Bahan kering (BK) 87,7 \%, abu 25,12\%, lemak kasar (LK) $14,23 \%$, serat kasar (SK) 29,40\%, protein kasar (PK) $3 \%$ termasuk asam amino, amine nitrat, glikosida, mengandung $\mathrm{N}$, glikilipida, vitamin $\mathrm{B}$, asam nukleat, bahan ekstrak tanpa nitrogen (BETN) 28,15\% termasuk karbohidrat, gula dan pati. Bonggol pisang memiliki komposisi $76 \%$ pati, 20\% air, sisanya adalah protein dan vitamin [1]. Komposisi kimia batang pisang dipengaruhi oleh berbagai faktor yaitu komposisi tanah, frekuensi pemotongan, fase pertumbuhan, pemupukan, iklim setempat dan ketersediaan air. Serat batang pisang mengandung 63\% selulosa, 20\% hemiselulosa dan 5\% lignin [2] dan [4].

Batang pisang dapat dimanfaatkan untuk diambil patinya, pati ini menyerupai pati tepung sagu dan tepung tapioca. Potensi kandungan pati bonggol pisang/batang pisang yang besar dapat dimanfaatkan sebagai alternatif bahan bakar yaitu bioetanol, selain itu juga umur panen dan usaha tani lebih fleksibel [1] dan [6]. Potensi kandungan pati batang pisang yang besar dapat dimanfaatkan sebagai alternatif bahan bakar yaitu bioetanol [5] dan [2], selain itu limbah batang pisang juga dapat digunakan sebagai bahan baku kertas.

Untuk mendukung program pemerintah dalam menghasilkan industri kreatif yang berbahan baku ramah lingkungan perlu ditingkatkan seperti pemanfataan limbah batang pisang yang dijadikan bahan baku kertas sebagai industri kreatif bagi masyarakat pedesaan dalam rangka peningkatan nilai tambah dan pendapatan bagi petani yang ada di Desa Pematang Rahim. Prospek pemanfaatan limbah batang pisang dari bahan yang terbuang menjadi suatu produk yang menjanjikan seperti bahan baku kertas untuk kerajinan dan ekonomi kreatif seperti pembuatan tempat tissu, tempat majalah, kotak tas, tempat gelas dan keranjang sampah [9].

Usaha kerajinan rumah tangga seperti pembuatan tas, pembuatan dompet, pembuatan tempat buku membutuhkan bahan baku kertas dan teknologi serta peningkatan pengetahuan masyarakat dalam mengelola limbah. Upaya mengubah cara pandang (mainset) individu maupun kelompok tani perlu ditingkatkan terutama dalam pemanfaatan dan pengolahan limbah batang pisang sebagai suatu usaha yang dapat memberikan nilai tambah bagi peningkatan pendapatan (added value) dan membuka lapangan usaha baru. Adanya partisipasi dari anggota masyarakat 
dan kelompok tani untuk mengelolah limbah dari batang pisang merupakan suatu langkah nyata yang memberikan pengaruh pada peningkatan perekonomian masyarakat dan sebagai potret keberhasilan pembangunan dari desa (sesuai program Nawacita).

\section{METODE}

Pengabdian kepada masyarakat dilaksanakan pada kelompok tani Karya Maju dan Kelompok Wanita Tani (KWT) (Canggam) Desa Pematang Rahim Kecamatan Mendahara Ulu Kabupaten Tanjung Jabung Timur Jambi dari bulan Mei sampai Oktober 2018. Teknologi yang digunakan adalah pemberdayaan anggota kelompok dalam pengolahan dan pemanfaatan limbah batang pisang yang banyak terdapat di Desa Pematang Rahim dan selama ini belum dimanfaatkan secara optimal.

Metode pendekatan yang dilaksanakan adalah melalui pendekatan on farm. Pelaksanaannya memperhatikan konsep efisiensi dan efektifitas penggunaan sumberdaya lokal dan peningkatan sumberdaya manusia (human resource). Dengan demikian terjadi peningkatan dan penggunaan limbah batang pisang sebagai bahan baku kertas untuk pembuatan kerajinan tangan industri rumah tangga yang ramah lingkungan.

Kegiatan ini dilakukan dengan penekanan pada metode partisipasi aktif kelompok sasaran. Kelompok sasaran yang terlibat dalam kegiatan ini adalah Kelompok Wanita Tani (KWT) (Canggam Craftfirra) dan kelompok tani Karya Maju. Pendekatan pada metode ini diharapkan kelompok sasaran dapat menguasai proses pengolahan limbah batang pisang dan pembuatan bubur kertas serta pembuatan kerajinan tangan. Mekanisme kegiatan ini akan dilaksanakan melalui beberapa tahap yaitu: penetapan kelompok sasaran, penyuluhan, kegiatan lapangan, praktek pembuatan kertas organik, pembinaan dan monitoring serta evaluasi kemajuan program.

Upaya untuk memperlancar kegiatan pengabdian ini, maka perlu dilakukan pendekatan terhadap perangkat desa, masyarakat serta penyuluh pertanian lapangan di Desa Pematang Rahim Kecamatan Mendahara Ulu yang dapat membantu dan melaksanakan rencana kegiatan ini. Khalayak sasaran yang ikut terlibat dan menunjang kegiatan ini adalah Kelompok Tani Karya Maju dan Kelompok Wanita Tani Canggam Craftfirra. Pemilihan kelompok sasaran tersebut didasarkan atas pertimbangan kepentingan dan permintaan dari Kelompok Wanita Tani untuk pengembangan usaha kerajinan tangan industri rumah tangga (home industry) serta tingginya tingkat permintaan dari kelompok wanita tani untuk mengadopsi teknologi. Berdasarkan pengalaman dari anggota kelompok tani, diharapkan mereka merupakan sasaran antara yang memiliki fungsi strategis dalam penyebaran inovasi baru bagi sasaran (masyarakat) yang lebih luas.

Dampak perubahan sangat terasa terutama yang berkaitan dengan pembuatan kerajinan tangan industri rumah tangga. Oleh karena itu untuk lebih meningkatkan penggunaan limbah batang pisang, diperlukan beberapa langkah proaktif berupa penyediaan batang pisang, alat pencacah batang pisang dan blender untuk pembuatan bubur kertas, screen dan perawatan alat. Disamping itu, kelompok tani harus mampu menyediakan bahana baku batang pisang secara kontinu, dengan melakukan budidaya pisang dan kegiatan lainnya. Pengolahan limbah batang pisang menghasilkan bubur kertas yang akan digunakan sebagai bahan baku untuk kertas dan dijadikan kerajinan tangan industri rumah tangga.

\section{Pengambilan Data}

Kegiatan ini dilakukan dengan penekanan pada metode partisipasi aktif kelompok sasaran. Pendekatan pada metode ini diharapkan kelompok sasaran dapat menguasai proses penyediaan, pengolahan dan pembuatan kerajinan tangan dari limbah batang pisang sebagai usaha industri rumah tangga. Teknologi yang akan digunakan adalah pemberdayaan anggota kelompok dalam pengolahan dan pemanfaatan limbah batang pisang dan memanfaatkan sumberdaya alam (nature resource) yang selama ini belum dimanfaatkan secara optimal.

Dampak perubahan dalam pengolahan limbah batang pisang sangat terasa terutama yang berkaitan dengan penanaman pisang yang sudah dilakukan oleh anggota kelompok, serta peningkatan pendapatan anggota kelompok wanita tani. Oleh karena itu untuk lebih meningkatkan usaha kerajinan tangan, diperlukan beberapa langkah proaktif berupa penyediaan peralatan, tempat pembuatan dan pengolahan limbah batang pisang untuk dijadikan bubur kertas yang sesuai 
dengan kebutuhan, dan perawatan peralatan lainnya. Tahapan proses pegolahan limbah batang pisang disajikan pada gambar 1 sampai gambar 8 sebagai berikut:

- Sosialisasi rencana kegiatan,

- Persiapan teknis untuk penanaman pohon pisang,

- Pengadaan peralatan/unit pengolahan batang pisang berupa alat pencacah dan alat blender,

- Pelatihan teknik pembuatan bubur kertas dan kerajinan tangan,

- Proses pembuatan dan aplikasi pemanfaatan bubur kertas untuk bahan kerajinan tangan.,

- Mempersiapkan limbah batang pisang,

- Batang pisang di cacah dengan alat pencacah batang pisang kemudian ditampung dalam bak penampungan

- Memblender hasil cacahan batang pisang,

- Hasil blender berupa bubur akan dimasukkan kedalam screen untuk dijadikan bahan baku kertas,

- Memotong dan membentuk ukuran kertas.

- Membuat kerajinan tangan dari kertas yang berasal dari limbah batang pisang.

- Setelah kerajinan tangan industri rumah tangga jadi maka hasilnya siap untuk dipasarkan.

- Keberlanjutan kegiatan melalui perluasan ke kelompok lain disekitar Desa Pematang Rahim

- Evaluasi dan pengendalian kualitas kerajinan tangan.

- Model yang dibangun secara terintegrasi antara kelompok tani yang menanam pisang dengan kelompok pengarajin limbah batang pisang.

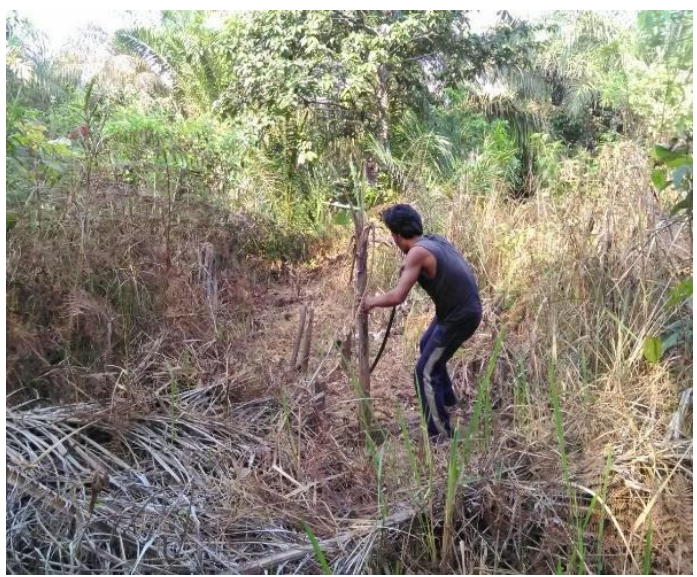

Gambar 1. Bahan baku batang pisang

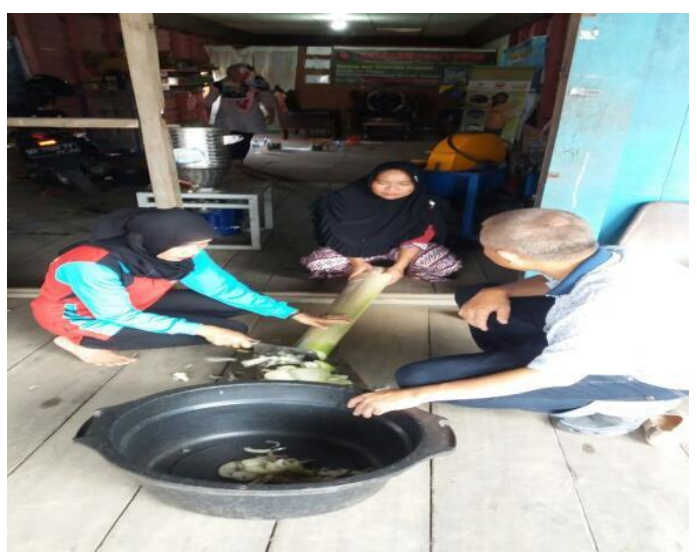

Gambar 3. Serat batang pisang
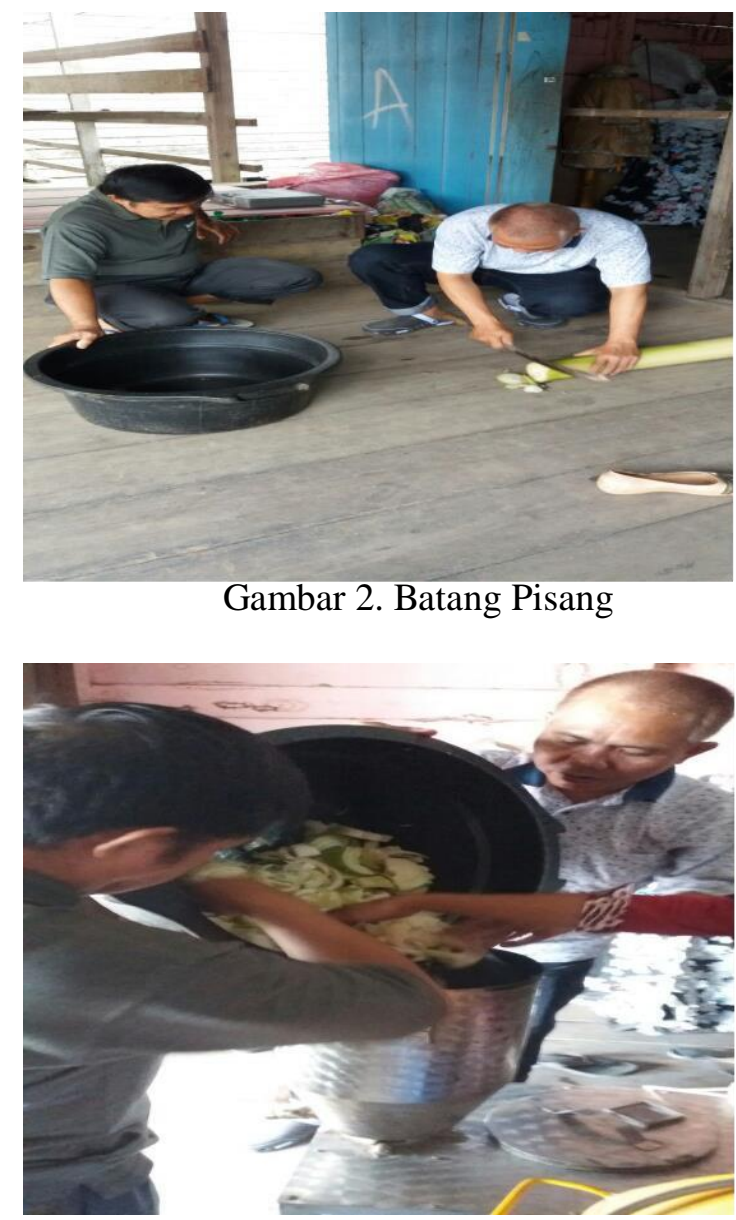

Gambar 4. Alat pencacah dan blender 


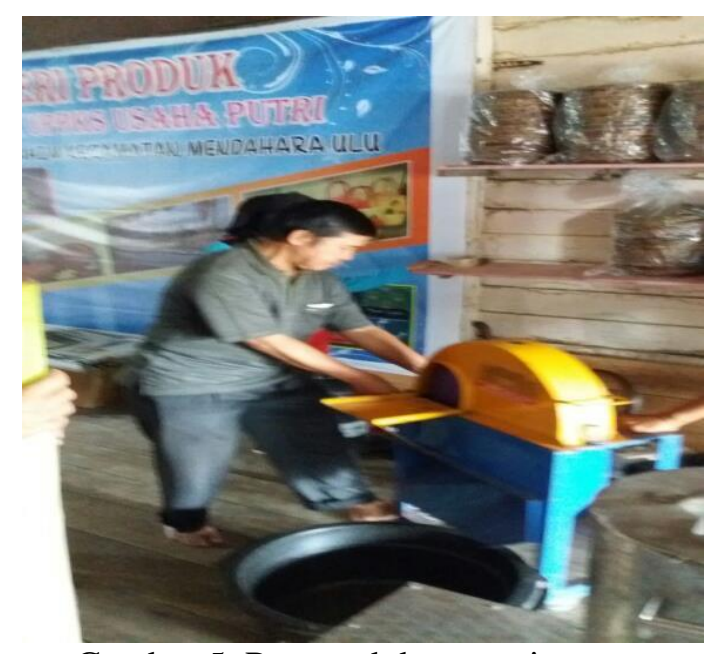

Gambar 5. Pencacah batang pisang

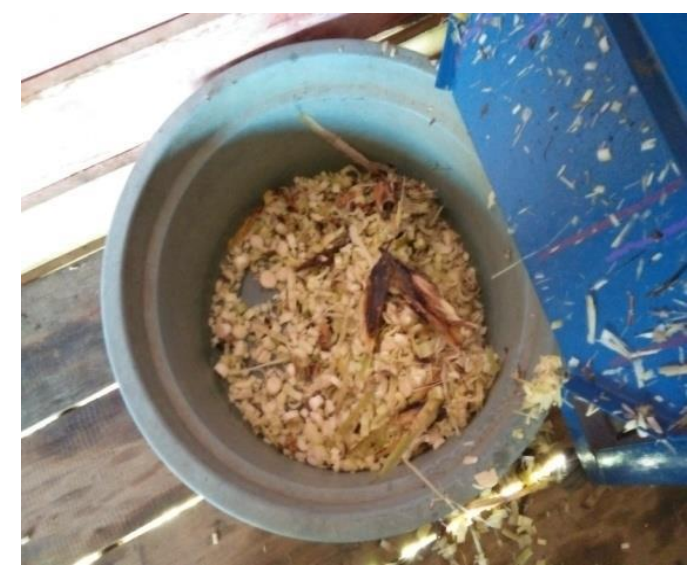

Gambar 7. Bahan untuk diblender

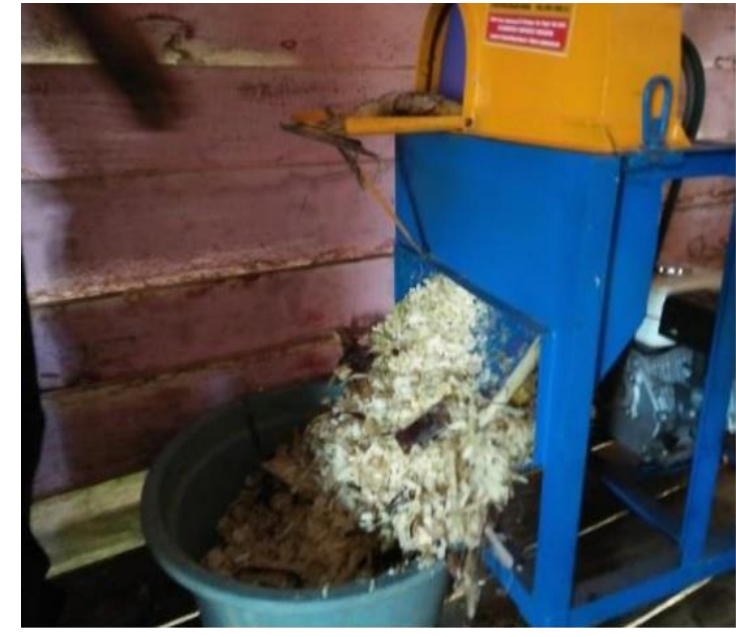

Gambar 6. Hasil cacahan

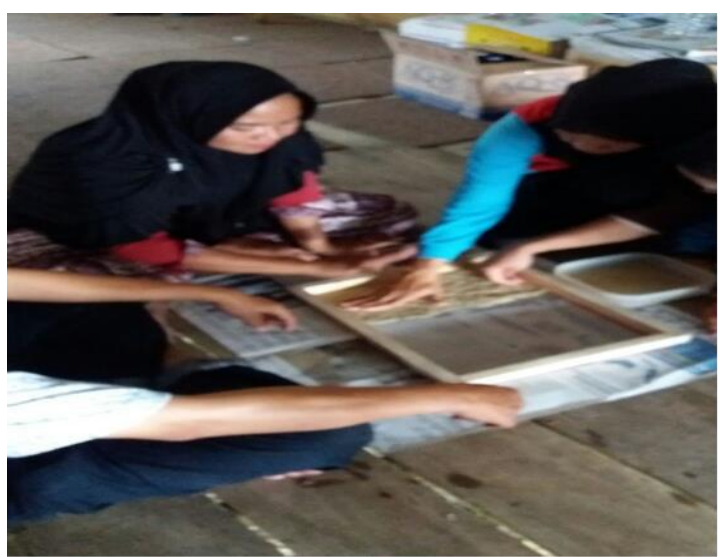

Gambar 8. Proses pencetakan

\section{HASIL DAN PEMBAHASAN}

Hasil dari Kegiatan pengabdian ini dapat dilihat pada peningkatan animo anggota kelompok tani Karya Maju dan kelompok wanita tani (KWT) Canggam Craftfirra untuk bersamasama mengembangkan usaha karajinan tangan dengan memanfaatkan limbah batang pisang sebagai bahan baku yang ramah lingkungan. Kelompok tani Karya Maju sudah aktif menanam pohon pisang \pm 200 pohon pisang. Sedangkan KWT Canggam Craftfirra sudah mampu menjual hasil kerajinan tangan, seperti keranjang, tempat air minum, tas dan lain-lain sehingga dapat membantu peningkatan pendapatan keluarga petani. Petani yang tergabung dalam kelompok tani Karya Maju dan KWT Canggam Craftfirra menginginkan adanya pemantauan, pelatihan, pembinaan dan pengawasan serta evaluasi dari kegiatan yang dilakukan. Pembinaan diarahkan pada ketrampilan kelompok sasaran dalam pembuatan, pemanfaatan limbah batang pisang dan perawatan alat serta menjaga kualitas dari hasil kerajinan tangan. Pemantauan dan pembinaan kegiatan ini dilakukan secara berkala setiap bulan setelah kegiatan penyuluhan, pelatihan pembuatan kertas organik dan kegiatan lapangan. Hasil kegiatan dapat dilihat pada gambar 9, 10, 11 dan 12. 


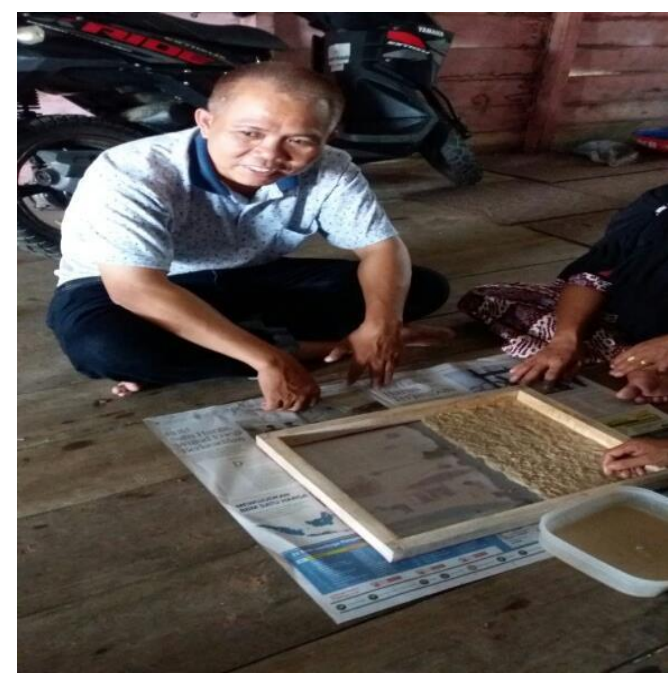

Gambar 9. Kertas organik dari limbah batang pisang

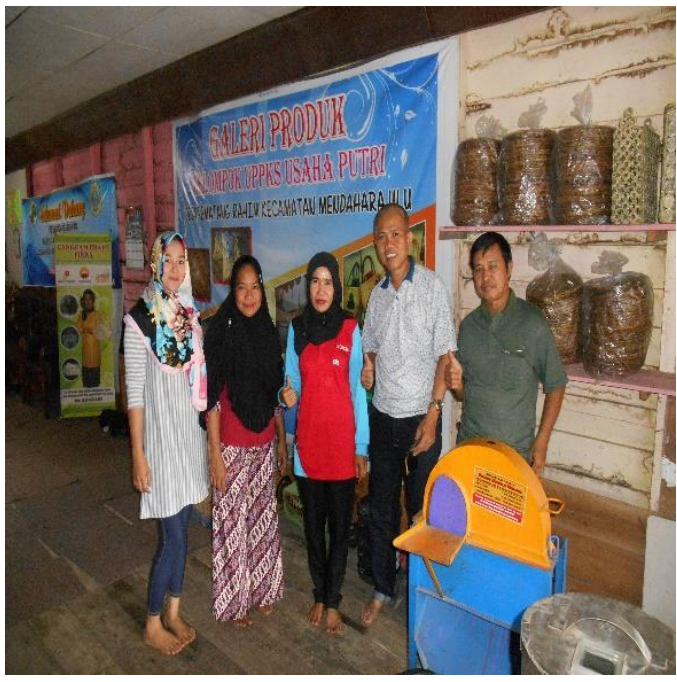

Gambar 11 Kelompok wanita tani

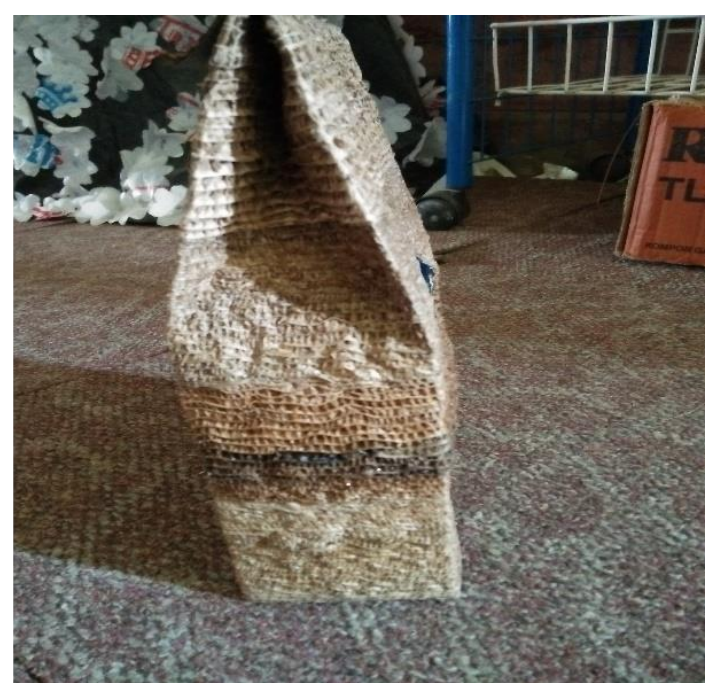

Gambar 10. Tas dari limbah batang pisang

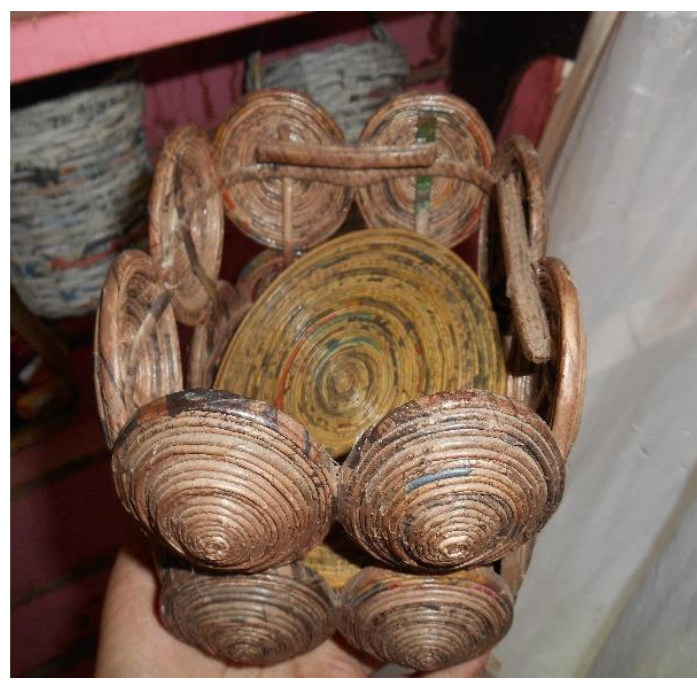

Gambar 12. Hasil kerajinan dari limbah batang pisang

Dalam mengevaluasi perubahan sikap petani setelah menerima penyuluhan dan demontrasi dalam waktu yang relatif lebih singkat diperlukan tindakan berkelanjutan. Untuk mengadopsi suatu teknologi baru khususnya bagi petani lokal sangat diperlukan suatu program lanjutan dan berkesinambungan dari waktu ke waktu terutama tentang strategi dan pengolahan limbah batang pisang serta pengembangan produk lain secara optimal.

Walaupun demikian dengan adanya penyuluhan dan aplikasi pemanfaatan limbah batang pisang telah menambah wawasan dan partisipasi anggota kelompok tani untuk memanfaatkan limbah batang pisang untuk dijadikan kerajinan tangan/handy craft sehingga dapat mendukung upaya peningkatan kesejahteraan keluargapetani.

Evaluasi dirancang untuk mengetahui pencapaian dari setiap tahapan kegiatan yang dilaksanakan. Berdasarkan evaluasi ini dapat diketahui faktor-faktor yang menentukan keberhasilan kegiatan pengabdian. Rancangan evaluasi terdiri atas penilaian motivasi khalayak sasaran, kemampuan dan ketrampilan anggota kelompok dan keberlangsungan kegiatan. Evaluasi tahap pertama dilakukan pada kegiatan penyuluhan dan kegiatan lapangan, sedangkan pada tahap kedua dilakukan terhadap keberlangsungan penerapan teknologi yang diintroduksi.

Indikator yang digunakan untuk penilaian pencapaian tujuan penerapan ini adalah perubahan sikap kelompok sasaran selama mengikuti kegiatan. Tolok ukur yang digunakan untuk menilai keberhasilan ini adalah anggota kelompok wanita tani sudah dapat mengolah dan 
memanfaatkan limbah batang pisang, kemudian pengurangan pengeluaran untuk membeli bahan baku karena dapat berasal dari daerah sendiri.

Saat ini karena peralatan pencacah dan blender batang pisang masih terbatas jumlahnya maka anggota kelompok wanita tani yang mendapat bantuan juga masih sedikit. Kedepan harapan dari anggota kelompok wanita tani agar mendapat bantuan alat dan sarana serta prasarana yang lebih permanen dari berbagai pihak.

Dampak dari pengolahan limbah batang pisang untuk pembuatan kerajinan tangan sudah dirasakan oleh anggota kelompok wanita tani dengan demikian untuk pemerataan dan desiminasi teknologi serta pemanfaatannya pada masa yang akan datang supaya mendapat dukungan dari program pemerintah atau stakeholder.

Keuntungan ekonomis yang diperoleh dari pengolahan limbah batang pisang adalah hasil kerajinan dari limbah batang pisang dapat dijual pada konsumen baik untuk Desa Pematang Rahim Kecamatan Mendahara Ulu, maupun untuk Kabupaten Tanjung Jabung Timur dan di jual di Provinsi Jambi. Pengrajin dapat melakukan sosialisasi hasil kerajinan mereka dengan mengikuti pameran dan pelatihan ataupun studi banding ke daerah lain. Sebagai contoh potensi kerajinan tempat minum laku dijual untuk satu set Rp 150.000,- (seratus lima puluh ribu rupiah), kemudian tempat buah-buahan dijual dengan harga Rp 50.000,-, tas dijual dengan harga Rp. 50.000,-. Sedangkan saat ini limbah batang pisang belum ada harganya. Jika masing-masing anggota kelompok dapat membuat kerajinan tangan sebanyak 10 set tempat minum dalam satu bulan maka anggota kelompok sudah mendapatkan keuntungan kotor sebanyak Rp. 1.500.000,-. Apabila pengarajin menekuni pekerjaannya dengan mempertahankan mutu hasil kerajinannya maka keuntungan yang diperoleh akan lebih banyak.

Berdasarkan hasil yang telah dirasakan manfaat kegiatan pengabdian oleh anggota KWT pengrajin Canggam Craftfirra, maka kelompok tani lain menginginkan agar program pemanfaatan limbah batang pisang terus berlanjut. Keinginan ini didukung oleh kemauan petani yang tinggi dan jumlah limbah batang pisang yang banyak tersedia. Keuntungan lain yang diperoleh petani adalah petani mendapatkan buah pisang, dan daun pisang serta batang pisang yang dapat dijual kepada pengrajin industri rumah tangga untuk meningkatkan kegiatan ekonomi kreatif.

\section{KESIMPULAN}

Hasil dari penyuluhan dan demontrasi secara langsung kepada kelompok tani di Desa Pematang Rahim, menunjukkan kelompok tani Karya Maju sudah melakukan penanaman pohon pisang, sedankan KWT Canggam Criftarra telah memanfaatan limbah batang pisang untuk dijadikan bubur kertas. Bubur kertas sebagai bahan baku untuk kerajinan/handy craft yang ramah lingkungan.

\section{SARAN}

Mengingat masih banyaknya bahan baku yang terdapat di Desa Pematang Rahim untuk dijadikan bubur kertas sebagai bahan baku kerajinan tangan serta masih terbatasnya motif dan pemasaran terhadap produk yang dihasilkan maka perlu diadakan suatu suatu bimbingan yang berkelanjutan terhadap design produk dan menjalin kerjasama dengan pihak swasta dalam pemasaran hasil sehingga dapat meningkatkan pendapatan keluarga petani dan pengrajin.

\section{UCAPAN TERIMA KASIH}

Terima kasih kepada Rektor Universitas Jambi, Ketua Lembaga Penelitian dan Pengabdian Pada Masyarakat, Direktur Pascasarjana UNJA, yang telah memberikan bantuan dana dan Ketua Kelompok Tani yang menyediakan fasilitas sehingga pengabdian ini dapat dilaksanakan. 


\section{DAFTAR PUSTAKA}

[1] Assegaf, F. 2009. Prospek produksi bioetanol bonggol pisang (Musa paradisiaca) menggunakan metode hidrolisis asam dan enzimatis. Universitas Jenderal Soedirman. Purwokerto.

[2] Kardono, B. S. 2010. Teknologi Pembuatan Etanol Berbasis Lignoselulosa Tumbuhan Tropis untuk Produksi Biogasoline. Program Insentif Penelitian dan Perekayasa, Lembaga Ilmu Pengetahuan Indonesia. Tangerang. Kecamatan Mendahara Ulu Dalam Angka.2017. BPS Kabupaten Tanjung Jabung Timur. CV. Suber Sentosa Multimedia.

[3] Manahan, S.E.1994. Environmental Chemistry, $6^{\text {th }}$ ed. Lewis Publisher, USA.

[4] Prihandana. 2007. Bioetanol ubi kayu bahan bakar masa depan. Agromedia. Jakarta.

[5] Rittmann, B.E and McCarty, 2001. Environmental Biotechnology: Principles and Applications, McGraw Hill International Ed., New York.

[6] Soetomo, 2006, Strategi-strategi Pembangunan Masyarakat, Yogyakarta: Penerbit Pustaka Pelajar

[7] Sumaryadi, I.N, 2005, Perencanaan Pembangunan Daerah Otonom dan Pemberdayaan Masyarakat, Jakarta: Penerbit Citra Utama

[8] Syarifuddin H dan Hamzah, 2017. Pengolahan Limbah Batang Pisang Sebagai Bahan Baku Kertas Ramah Lingkungan Di Desa Pematang Rahim. Laporan Pengabdian Kepada Masyarakat, LP2M Universitas Jambi

[9] Utami, I. P. 2013. Pembuatan Bioetanol Dari Bonggol Pisang Dengan Hidrolisis Menggunakan Enzim alfa-amilase dan glukoamilase. Skripsi. Universitas Sebelas Maret. Surakarta. 